\title{
Detection of RpoS Gene in Escherichia Coli 0157:H7 and non-0157 and Their Survival Pattern in Water Treatment Methods
}

\section{Olowe, B. M. ${ }^{* a}$, Adelegan, O. ${ }^{\text {b }}$}

a Department of Science Laboratory Technology, Faculty of Science, Ekiti State University, Ado-Ekiti, Ekiti State.

${ }^{b}$ Department of Medical Microbiology and Parasitology, Afe Babalola University, Ado-Ekiti, Nigeria.

\author{
Received: $1^{\text {th }}$ Apr 2020 Revised: 7h $^{\text {May }} 2020$ Accepted: 8 ${ }^{\text {th }}$ sept 2020 DOI: https://doi.org/10.31559/CRMI2020.1.1.3
}

Abstract: This study aimed to detect presence of RpoS gene in Escherichia coli 0157:H7 and non-0157 and investigate their survival pattern in different water treatment methods. A total of fifteen serologically and molecularly identified E. coli was selected from a previous work, out of which eight were Escherichia coli 0157 and seven were E. coli non-0157. From among these, S30 and S89 identified isolates served as presentative E. coli 0157:H7 and non-0157 respectively for survival studies. The water treatment methods used employed included: use of silver, lime, storage, acidification (low pH), high temperature and Moringa oleifera. Survival pattern of the test organisms under the influence of these methods were carried out using standard techniques. Molecular detection of stress response gene, RpoS, in the fifteen (15) test organisms was performed following manufacturer's instruction. Results showed that for both test organisms, silver was bactericidal at high concentration while storage allows their survival up till 21 days though with a reduction in cfu. Both organisms showed low survival at pH 9 while E. coli 0157:H7 and non-0157 could survive at $\mathrm{pH} 4$ and 6 respectively. E. coli 0157:H7 survived better than non-0157 at high concentration of lime. While both survived at low temperature, E. coli 0157:H7 survive better at $60^{\circ} \mathrm{C}$. Sunlight and chlorine showed mild and complete bactericidal action respectively with increased exposure time for both test organisms. Moringa oleifera was only effective at a reduced concentration on the two organisms. Detection of $R p o S$ genes showed that only $66.7 \%$ carried the gene in them while $33.3 \%$ did not. Findings from this study show that the possession of stressed genes in bacteria causing waterborne disease could allow these organisms to survive water treatment methods adopted in many under developed countries or rural communities. This suggests a threat to health of these communities.

Keywords: E. coli O157: H7; E. coli non-0157; water treatment methods; RpoS genes; Survival pattern.

\footnotetext{
${ }^{*}$ Corresponding author

Olowe, B. M

Department of Science Laboratory Technology, Faculty of Science, Ekiti State University, Ado-Ekiti, Ekiti State.

E-mail: busatopol@gmail.com
} 


\section{Introduction}

The availability of potable water is a function of appropriate treatment methods applied to it. Several treatment methods which include biological, physical and chemical methods are being employed to ensure availability of potable water to communities or homes. Consequently, reducing incidences of waterborne diseases in communities or households. However, in under developed countries or rural communities where potable water is not available to the residents, several readily available and cheap methods of water treatment are employed to safeguard their health. Among these methods include use of silver, lime, acidification (low $\mathrm{pH}$ ), storage, sunlight (Solar Disinfection), low and high temperature and Moringa oleifera seed. As a matter of fact, some of these methods may not actually be effective in reducing bacterial load of the water as some enteric bacteria causing waterborne diseases have defied these treatments methods.

Among these enteric bacteria is Escherichia coli which exhibits a high degree of catabolic flexibility, which conferred a clear fitness (survival) advantage in its secondary habitats such as soil and water (Ihssen and Egli, 2005). Survival of E. coli in water varies depending upon species, strain, and environmental pressures, but the mechanisms governing their fate are poorly understood (Gordon et al., 2006; Semenov et al., 2009). Escherichia coli 0157:H7 poses health risk when they are excreted into the environments. Various studies have documented the ability of E. coli 0157 to survive for extended period of time within secondary habitats including water, sediment, and vegetation (LeJeune et al., 2004; LeJeune et al., 2004; Islam et al., 2004; Semenov et al., 2009; Oliveira et al., 2012; Saxena and Sewak, 2016).

Escherichia coli 0157 may survive and even grow in sterile freshwater at low carbon concentrations, which is in contrast to the common conception that the organism will die out over time in such strongly carbon-limited environments (Vital et al., 2008). Moreover, because of the production of RpoS, E. coli is able to rapidly adapt to and tolerate diverse stress conditions. It was thus revealed that high osmolarity, extremes and fluctuations of temperature, low $\mathrm{pH}$ and low growth rate induce rpoS in E. colicells (Elsas et al., 2011). Also, E. coli can enter a dormant, that is, viable but non-culturable state in which the cells cannot be easily recovered on standard laboratory media, but are still present as viable cells. This state can be triggered by stress conditions that are imposed, for instance, by low temperature (for example, $4^{\circ} \mathrm{C}$ ) or toxic metals for example, copper, lead, mercury and cadmium (Bhagat et al., 2016). Although, the resistance to starvation of $E$. coli leads to its persistence in the environments, predation, substrate competition and antagonisms by indigenous microflora lead to a negative effect on its survival in the environment (Wcislo and Chrost, 2002; Elsas et al., 2011).

Several reports on outbreak of waterborne diseases caused by E. coli 0157 and non-0157 have been documented but there have been little or no information on their survival in the environment and under the influence of water treatment methods. And studies of factors affecting the survival of Escherichia coli in natural waters would be of great interest due to the importance of this microorganism as the primary index of faecal contamination of water (Edberg et al., 2000; WHO, 2006). Therefore, this study aimed to detect the presence of $R p o S$ gene in Escherichia coli 0157:H7 and non-0157 and investigate their survival pattern in different readily available and cheap water treatment methods.

\section{Materials and Methods}

Test organisms: From a previous study, a total of fifteen (15) biochemically, serologically and molecularly identified $E$. coli were selected. The identified isolates were S2, S10, S30, S35, S70, S71, S89 and S152 from well, S3B, S82 and S177 from stream, S31 and S33 from borehole and S34 and S202 from pipe-borne water samples. Among which, eight (8) were identified as E. coli 0157:H7 and seven (7) were $E$. coli non-0157. Isolate S30 and S89 were used as presentative E. coli $0157:$ H7 and E. colinon-0157 respectively for the survival studies while the whole fifteen identified isolates were used for molecular studies.

Experiments: Investigation on physicochemical characteristics of E. coli 0157 (S30) and E. coli non0157 (S89) survival in water were performed under varied physicochemical factors using the standard techniques employed by Wcislo and Chrost (2000) and Sakyi and Asare (2012). These factors included low and high temperature, $\mathrm{pH}$, chlorine, silver nitrate, lime, sunlight and Moringa oleifera.

Preparation of Inoculum for Survival Experiments: The inoculum was prepared as described by Wcislo and Chrost (2000) and Al-Qadiri et al. (2011). S30 and $\mathrm{S} 89$ were grown in $50 \mathrm{ml}$ of Tryptone Soy Broth (TSB) (Lab M, LAB011 U.K.) and incubated at $37^{\circ} \mathrm{C}$ for 24 hours. After incubation, $10 \mathrm{ml}$ of S30 and S89 broth were centrifuged using bench top centrifuge (AccuSpin model 400 bench top centrifuge, Fisher Thermo Scientific, Pittsburgh, PA) at 3000 rpm for 15 minutes. To eliminate any effect of broth components and bacterial metabolites, the resultant pellets were re-suspended in $10 \mathrm{ml}$ of sterile $0.85 \%$ (wt/vol) saline solution and centrifuged as before. After the second centrifugation, the supernatant was decanted, and the pellets were re-suspended in $10 \mathrm{ml}$ of the same sterile saline solution corresponding to approximately $10^{6} \mathrm{cfu} / \mathrm{ml}$. 
Effect of Silver Nitrate: Different concentration of $0.01 \mathrm{mg} / \mathrm{l} \mathrm{AgNo}_{3}$ was prepared by doubling-fold dilution method to give 1.0, 0.5, 0.25, 0.125 and 0.0625 concentrations in the test tubes. After which, one ml of dilution $10^{6}$ of the prepared inoculums was added to each of the test-tubes. The control test-tube did not contain silver nitrate. The time of exposure to $\mathrm{AgNO}_{3}$ was an hour.

Effect of Storage: nine test-tubes consisting of sterile $9 \mathrm{ml}$ water samples each inoculated with $1 \mathrm{ml}$ of dilution $10^{6}$ of the prepared inoculums were stored at room temperature for 24days. The presence and proportion of test organisms at every 3 days interval were investigated and recorded. The test-tubes serving as control were plated immediately to detect the presence and proportion of E. coli 0157 and non0157.

Survival at Low and High pH: Nine ml water sample each was dispensed into seven test-tubes and the water in each test-tube was adjusted to the desired $\mathrm{pH}(3.0,4.0,5.0,6.0,7.0$ and 9.0) with $1 \mathrm{M}$ phosphate buffer. The tubes were sterilized for 15 mins at $121^{\circ} \mathrm{C}$. The $\mathrm{pH}$ of the water did not change after autoclaving. The tubes were inoculated with $1 \mathrm{ml}$ of dilution $10^{6}$ of the prepared inoculums. Also, there was a control with no adjusted $\mathrm{pH}$ which was inoculated with the same volume of prepared inoculums. The test-tubes were incubated for an hour.

Effect of Lime: The limes were washed cleaned after which was wiped with ethanol and then peeled aseptically in order to extract the liquid content. It was filtered using No 1. Whiteman filter paper. Different concentrations of the filtrate were prepared by doubling-fold dilution method to give 1.0, 0.5, 0.25 , $0.125,0.0625$ and $0.03125 \mathrm{mg} / \mathrm{ml}$ concentrations in different test tubes. Then $1 \mathrm{ml}$ of dilution $10^{6}$ of the prepared inoculums was added to each of the testtubes. The control test-tube did not contain lime. The time of exposure to lime was an hour.

Survival at Low Temperatures: Sterile $9 \mathrm{ml}$ water sample in different sterile test-tubes were inoculated with $1 \mathrm{ml}$ of dilution $10^{6}$ of the prepared inoculums. Then they were aseptically stored at $22^{\circ} \mathrm{C}, 8^{\circ} \mathrm{C}$, and $0^{\circ} \mathrm{C}$ for 5,7 , and 2 days, respectively. These storage intervals were selected because some individuals keep drinking water at room temperature for 2 to 5 days, whereas others prefer to refrigerate water and consume it within a week. The storage at $22^{\circ} \mathrm{C}$ served as control.

Effect of High Temperature $\left(40^{\circ} \mathrm{C}, 50^{\circ} \mathrm{C}\right.$ and $\left.60^{\circ} \mathrm{C}\right)$ : Sterile $9 \mathrm{ml}$ water sample in different sterile testtubes were inoculated with $1 \mathrm{ml}$ of dilution $10^{6}$ of the prepared inoculums. The test-tubes were heated till the contents were brought to $40^{\circ} \mathrm{C}, 50^{\circ} \mathrm{C}$ and $60^{\circ} \mathrm{C}$ for about $5 \mathrm{mins}$. The test-tubes serving as control was not exposed to heating.

Effect of Sunlight: This was carried out on an intense sunny day. Sterile $9 \mathrm{ml}$ water sample in different sterile test-tubes were inoculated with $1 \mathrm{ml}$ of dilution $10^{6}$ of the prepared inoculums. The test-tubes were exposed to intense sunrays at different time interval with the exception of the control.

Effect of Chlorine: Sterile $9 \mathrm{ml}$ water sample in different sterile test-tubes were inoculated with $1 \mathrm{ml}$ of dilution $10^{6}$ of the prepared inoculums. $0.1 \mathrm{ml}$ of $0.25 \mathrm{mg} / \mathrm{ml}$ of chlorine was added to each test-tube except the control. The exposure time was 30 secs., 60 secs., 90 secs. and 120 secs.

Effect of Aqueous Extract of Moringa oleifera Seeds: Seeds of $M$. oleifera were collected from $M$. oleifera tree. The seeds were de-shelled to get the kernels. The Seed kernels were further dried at ambient temperature for five days. The white kernels were milled into a fine powder using a blender (Marlex Electroline Dabhel, Daman). Then $10 \mathrm{~g}$ was weighed and soaked in sterile $100 \mathrm{ml}$ of distilled water in a beaker for $24 \mathrm{hrs}$. The extract was then filtered using a filter paper and different concentrations, 0.05, 0.1, $0.15,0.20 \mathrm{mg} / \mathrm{ml}$ and neat of the extract were prepared. Then $9 \mathrm{ml}$ sterile water sample in a conical flask inoculated with $1 \mathrm{ml}$ of dilution $10^{6}$ of the prepared inoculums was used for the experiment. From each concentration of the extract, $1 \mathrm{ml}$ was taken aseptically and poured into the content of the conical flask and mixed thoroughly. This was done because it has been documented that, $4 \alpha-4$ rhamnousyloxy-benzyf-isothiocynate, the active antimicrobial agent in M. oleifera is readily soluble in water and is non-volatile (Bichi, 2013). The mixture was allowed to stand overnight at room temperature. The negative control conical flask did not contain any $M$. oleifera. One $\mathrm{ml}$ from each conical flask was taken and plated on EMB agar plate and incubated at $24 \mathrm{hrs}$ at $37^{\circ} \mathrm{C}$.

Recovery of E. coli 0157 and non-0157 on EMB Agar. S30 and S89 counts and identification were determined by plating $1 \mathrm{ml}$ from each test-tube of the test experiment on EMB Agar after the exposure duration of each test experiment. These were incubated at $37^{\circ} \mathrm{C}$ for $24 \mathrm{hrs}$. Thereafter, the number of E. coli 0157 (S30) and non-0157 (S89) were counted and recorded in $\log _{10} \mathrm{cfu} / \mathrm{ml}$

\section{Molecular Detection of RpoS Genes}

E. coli $0157(n=8)$ and E. coli non-0157 ( $n=7)$ were grown overnight at $37 \mathrm{oC}$ and standard PCR techniques were used, following manufacturer's instruction. The primer used is shown in Table 1. 
Table (1): PCR primers used in this study

\begin{tabular}{lllll}
\hline $\begin{array}{l}\text { Primer } \\
\text { set }\end{array}$ & $\begin{array}{l}\text { Target } \\
\text { gene }\end{array}$ & Sequence $\left(5^{\prime} \rightarrow 3^{\prime}\right)$ & $\begin{array}{l}\text { Size of PCR } \\
\text { Product } \\
\text { (bp) }\end{array}$ & References \\
\hline A & E. coli & 5'GCGTTGCTGGACCTTATC3' $^{\prime}$ & 250 & $\begin{array}{l}\text { Parry-Hanson } \\
\text { et al. (2010) }\end{array}$ \\
& Rpos & 3'GAATAGTACGGTTTGGTTCATAAT5' $^{\prime}$ & & \\
\hline
\end{tabular}

\section{Results}

The results from this study showed a characteristic difference in the survival of $E$. coli 0157:H7 and E. coli non- 0157 under varied physicochemical factors as follows:

Effect of silver nitrate: Results showed that the two strains exhibited the same response to silver nitrate. At higher concentrations of dilution 1, 0.5, 0.25, 0.125 , silver nitrate was bactericidal on the two strains while few colonies were able to survive at lower concentration of dilution 0.0625, 0.0312, 0.0156 (Fig. 1).

Effect of storage: It was observed that both strains persisted in drinking water up till 21 days at room temperature. Although, their $\log _{10} \mathrm{cfu} / \mathrm{ml}$ decreased with days when compared with the control, that is, from $7.64 \log _{10} \mathrm{cfu} / \mathrm{ml}$ to $6.42 \log _{10} \mathrm{cfu} / \mathrm{ml}$ and 7.68 $\log _{10} \mathrm{cfu} / \mathrm{ml}$ to $6.95 \log _{10} \mathrm{cfu} / \mathrm{ml}$ for E. coli 0157 and non-0157 respectively (Fig. 2).

Effect of pH: The result in Fig. 3 shows that while $E$. coli 0157 was able to survive at $\mathrm{pH} 4$, E. colinon-0157 was unable to survive at that same $\mathrm{pH}$. Although, it was observed that $E$. coli non-0157 was able to survive at slightly acidic condition (pH6). It was also shown that the survival of both strains was low at $\mathrm{pH}$ 9 with reduced $\log _{10} \mathrm{cfu} / \mathrm{ml}$.

Effect of lime: Fig 4 depicts that E. coli 0157 survived better at higher concentration (1.0 and 0.5$)$ of lime than E. coli non-0157. However, their $\log _{10} \mathrm{cfu} / \mathrm{ml}$ increased inversely with concentration of the lime.

Effect of low and high temperature: Varied survival pattern of the two strains were observed under low and high temperature (Fig. 5). Both strains survived at low temperature of $4{ }^{\circ} \mathrm{C}$ to $20^{\circ} \mathrm{C}$ but as the temperature increased, there was a better survival of E. coli 0157 than E. coli non-0157.

Effect of sunlight: Sunlight experiment revealed mild bactericidal effect of sunlight on the two strains as their $\log _{10} \mathrm{cfu} / \mathrm{ml}$ decreased with length of exposure from $6.87 \log _{10} \mathrm{cfu} / \mathrm{ml}$ to $5.0 \log _{10} \mathrm{cfu} / \mathrm{ml}$ and 7.60 $\log _{10} \mathrm{cfu} / \mathrm{ml}$ to $6.30 \mathrm{cfu} / \mathrm{ml}$ of $E$. coli 0157 and non0157 respectively (Fig. 6).

Effect of Chlorine: Chlorine exhibited a quick and total bactericidal effect on both strains as there was no survival even after $30 \mathrm{sec}$ of exposure (Table 2).

Effect of aqueous extract of Moringa oleifera: Fig. 7 shows that the extract was more effective in reducing the $\log _{10} \mathrm{cfu} / \mathrm{ml}$ of the two strains at higher concentration than at lower concentration. However, it was observed that at low concentration of dilution 0.062 , there was an increase in $\log _{10} \mathrm{cfu} / \mathrm{ml}$ in both strains when compared with the control. This revealed that the extract was utilized as nutrient by

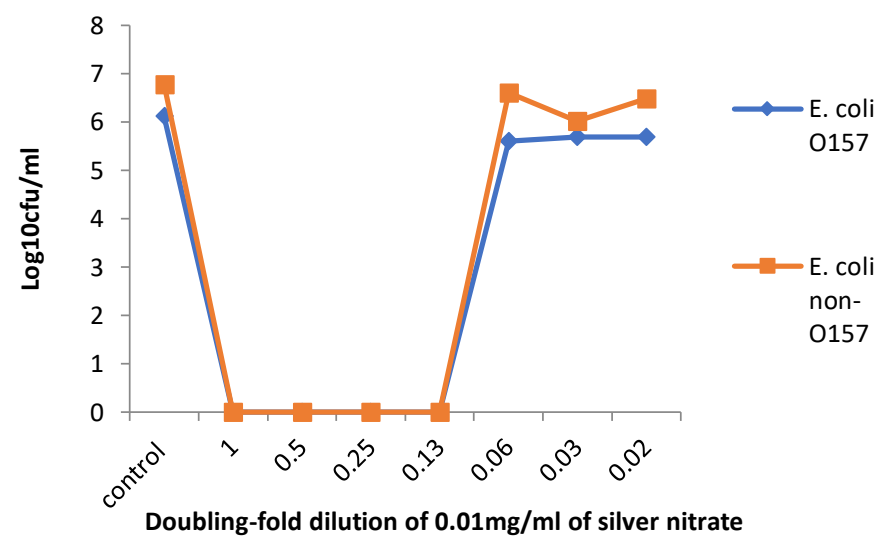

Fig (1): Effect of Silver Nitrate on E. coli 0157 and E. coli non-0157 in Drinking Water

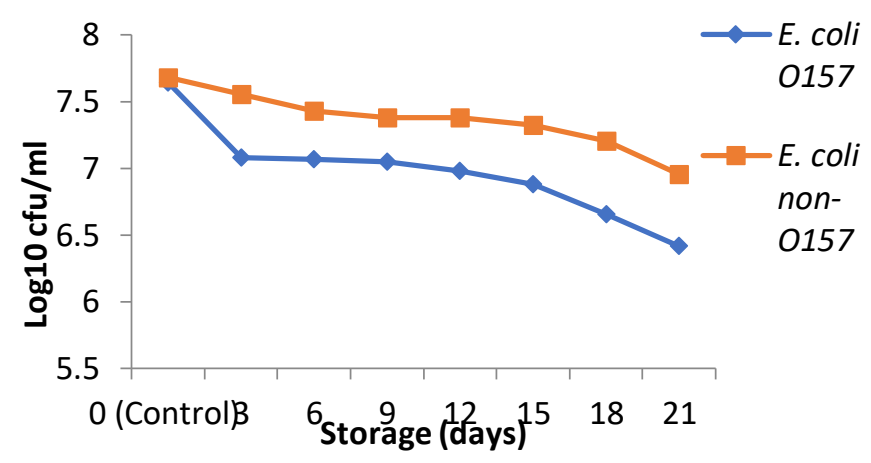

Fig (2): Effect of Storage on E. coli 0157 and E. coli non0157 in Drinking Water

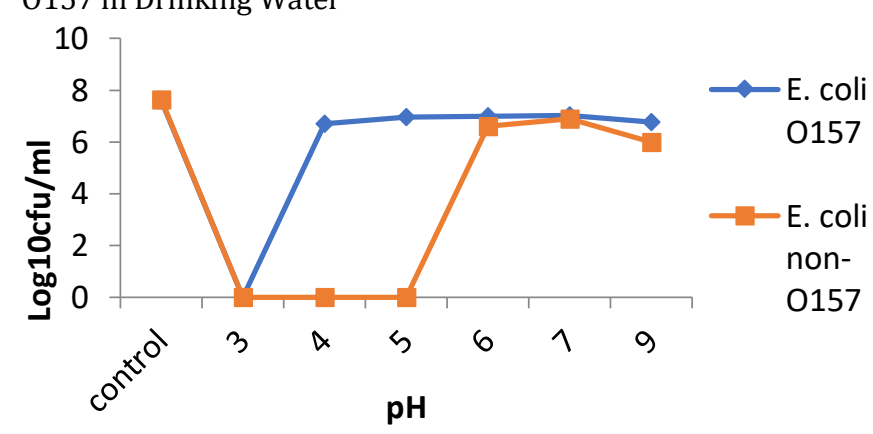

Fig (3): Effect of $\mathrm{pH}$ on E. coli 0157 and E. coli non-0157 in Drinking Water 


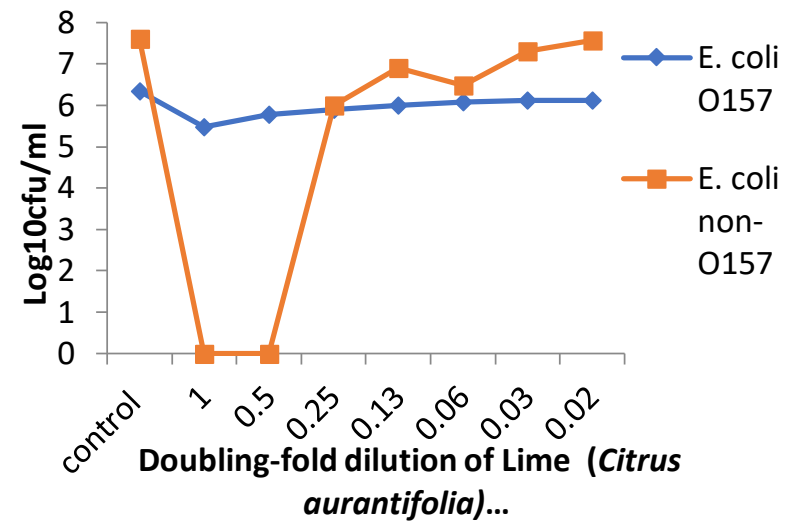

Fig (4): Effect of lime on E. coli 0157 and E. coli non-0157 in Drinking Water

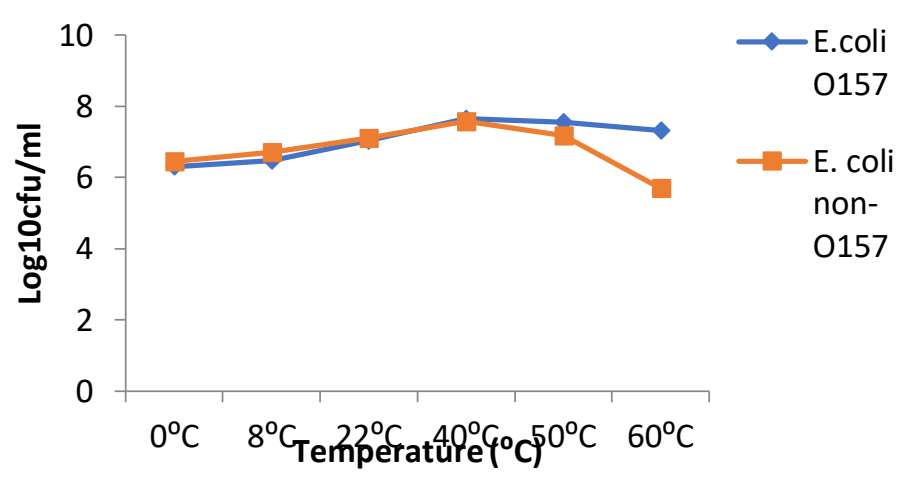

Fig (5): Effect of Low and High Temperature on E. coli 0157 and E. coli non-0157 in Drinking Water

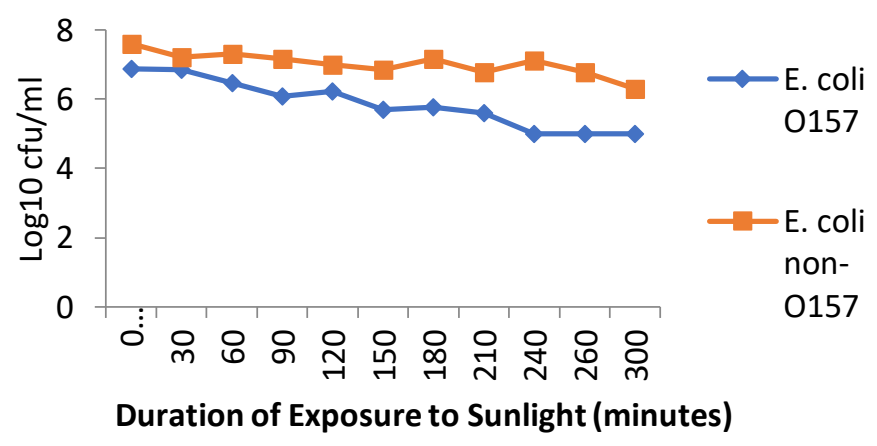

Fig (6): Effect of Sunlight on E. coli 0157 and E. coli non0157 in Drinking Water

Table (2): Effect of $0.25 \mathrm{mg} / \mathrm{ml}$ of Chlorine on E. coli 0157 and E. coli non-0157 in Drinking Water

\begin{tabular}{|c|c|c|c|}
\hline $\begin{array}{l}\text { Exposure } \\
\text { (secs.) }\end{array}$ & Time & $\begin{array}{l}\text { E. coli } 0157 \\
\left(\log _{10} \mathrm{cfu} / \mathrm{ml}\right)\end{array}$ & $\begin{array}{l}E . \text { coli Non- } \\
0157 \\
\left(\log _{10}\right. \\
\text { cfu/ml) }\end{array}$ \\
\hline 30 & & 0.00 & 0.00 \\
\hline 60 & & 0.00 & 0.00 \\
\hline 90 & & 0.00 & 0.00 \\
\hline 120 & & 0.00 & 0.00 \\
\hline Control & & 6.1139 & 7.6335 \\
\hline
\end{tabular}

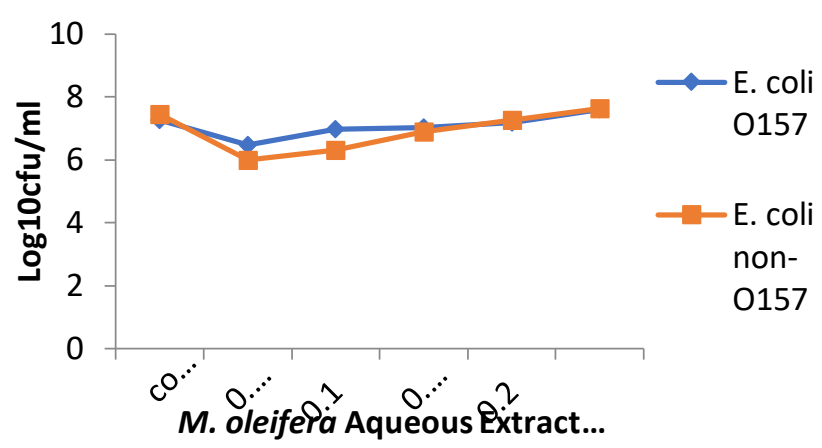

Fig (7): Effect of Moringa oleifera Aqueous Extract on $E$. coli 0157 and E. coli non-0157 in Drinking Water

Molecular detection of $R p o S$ gene: figure 8 revealed that some of the isolates possess stress response gene (RpoS) which allowed their survival in a secondary habitat (water). All the isolates were positive for $R p o S$ gene of $250 \mathrm{bp}$ except for isolates in lane 4, 5, 6, 8 and 9 which showed absence of the gene in them, that is, only $66.7 \%$ carried the gene in them while $33.3 \%$ did not.

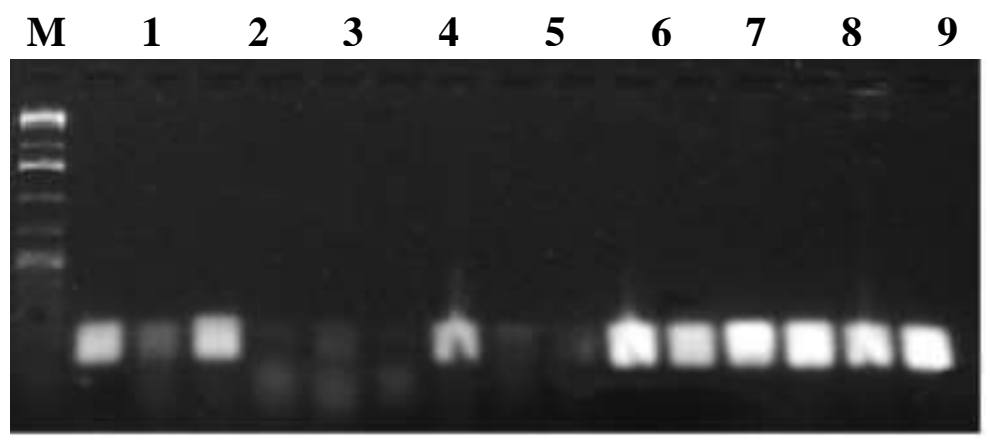

Fig (8): Gel Electrophoresis for RpoS gene (250p)

Lane 1-8 (E. coli non-0157), Lane 9-15 (E. coli 0157), Lane M (100bp DNA size marker) Lane 1 (S71 from well sample), Lane 2 ((S177 from stream sample), Lane 3 (S31 from borehole sample), Lane 4 (S70 from well sample), Lane 5 (S89 from well sample), Lane 6 (S152 from well sample), Lane 7 (S202) from pipe-borne water sample), Lane 8 (S34 from pipe-borne sample), Lane 9 (S33 from borehole sample), Lane 10(S3B from stream sample), Lane 11 (S2 from well sample), Lane 12 (S35 from well sample), Lane 13 (S82R from stream sample), Lane 14 (S30 from well sample) and Lane 15 (S10 from well sample).

\section{Discussion}

In various homes and industries where water is being consumed or used, several water purification methods are being adopted to eliminate or reduce the microbial load of the water. But surprisingly, few pathogenic microorganisms have devised several mechanisms in them to survive these purification methods. Among these treatment methods, silver has been used as an effective water disinfectant for many 
decades (Kim et al., 2004). Both the Environmental Protection Agency (EPA) and the World Health Organization (WHO) regard silver as safe for human consumption (WHO 1996). Gram-negative bacteria appear to be more sensitive than Gram positive species because gram-positive species have a thicker peptidoglycan layer than do gram-positive species (Kawahara et al. 2000). Its disinfection was found to be toxic to microorganisms and this was confirmed in this study as it inhibited the growth of the two strains of $E$. coli after an hour exposure. This corroborates the findings of Russell and Hugo (1994) who reported that silver was found effective at preventing growth of Pseudomonas fluorescens and Pseudomonas aeruginosa in water supplies. Application of little quantity of silver is not health threatening, but in larger amounts, some silver compounds may be toxic, because silver ions have a high affinity for sulphur hydryl and amino groups, and therefore complexation with amino acids, nucleic acids and other compounds may occur in the body (SilvestryRodriguez et al., 2007).

Effect of storage in this study revealed that the organisms were able to persist in sterile drinking water up till 21 days, although, with a reduction in their $\log _{10} \mathrm{cfu} / \mathrm{ml}$ at the end of 21 days. This corroborates with the study of Berthe et al. (2013) who also recorded that persistent strain of $E$. coli were able to survive up to 14 days. This is further validated by the observation of Adesioye and Ogunjobi (2013) who reported that E. coli survive better in sterile drinking than in unsterile drinking water and that a general decrease of $E$. colicount with time was noticed.

Also, it was observed that E. coli 0157:H7 survived better than E. coli non-0157 at low $\mathrm{pH}$. This finding strengthened the studies by other researchers who reported the ability of E. coli 0157 to survive in an acidic medium (Oshoma et al., 2009; Albashan, 2009; Parry-Hanson et al., 2010). Although, E. coli 0157 strains still showed different capacities to survive in acidic environment, they are superior in their survival over E. coli non-0157 (Bergholz and Whittam, 2007). Variation in rpoS induction levels might explain the variability in acid resistance of different $E$. coli 0157:H7 strains. The effectiveness of lime (Citrus aurantifolia) in water purification and in controlling pathogens causing intestinal disorder has been documented (Nannapaneni et al., 2008; Jacob and Sumathy, 2010; Ojiezeh et al., 2011). Although, this study showed that E. coli 0157:H7 was still able to survive at high concentration of the lime possibly due to its ability to adapt to an acidic environment, $E$. colinon 0157 was not. This is of health significance in a community setting where lime is being used in purifying water. This suggests that E. coli 0157 will still survive in such water. Researchers have also revealed that the use of lime in combination with sunlight will solve this problem (http://releases,jhu.edu).
For solar disinfection (SODIS) which uses the sun's energy to provide an economically feasible means of providing safe drinking water. SODIS is a free and effective method usually applied at the household level and is recommended by World Health Organization as a viable method for household water treatment and safe storage. Under the right conditions (intense sunlight), solar water disinfection, or SODIS, could solve the problem of water contamination. Studies have shown that when unpotable water sample stored in transparent bottle is exposed to sunlight for about five or six hours or 48 hours in a cloudy weather, there was a significant reduction in coliform forming unit of $E$. coli after the exposure (Wcislo and Chrost, 2000; Esemikose and Azeez, 2013). These confirm the findings on sunlight effect in this study. The ultraviolet radiation from sunlight creates highly reactive oxygen species such as superoxide $\left(\mathrm{O}^{2}-\right)$, hydrogen peroxides $\left(\mathrm{H}_{2} \mathrm{O}_{2}\right)$, and hydroxyl radicals $\left(\mathrm{OH}^{-}\right)$which in turn oxidize microbial cellular components such as nucleic acids, enzymes, and membrane lipids, which kill the microorganisms (Esemikose and Azeez, 2013). Effect of low and high temperature on the two strains showed that the two strains were able to survive at low temperature though, their count were low compared to their control. However, E. coli 0157:H7 survived better when exposed to high temperature than E. coli non-0157. This may probably be as a result of the induction of the sigma factor, $r p o S$, which allows E. coli 0157 to overcome environmental stresses. In a similar study, Ansay et al. (1999) reported that E. coli 0157:H7 survives freezing with some decline in cfu. Equally, Clavero and Beuchat (1996), recovered 5 strains of E. coli $0157: \mathrm{H} 7$ at $60^{\circ} \mathrm{C}$ for 0,15 and 30 minutes. This signifies that, E. coli 0157: H7 could survive temperatures above $45^{\circ} \mathrm{C}$. Moringa oleifera aqueous extract was able to reduce count of both strains in drinking water samples. This is made possible due to an active antimicrobial agent, $4 \alpha$-4-rhamnousyloxy-benzyf-isothiocynate, present in the seed and it is readily soluble in water. This finding is validated by observations made by some researchers (Suarez et al., 2003; Suarez et al., 2005; Fisch etal., 2004; Thilza etal., 2010; Bukar et al., 2010 and Bichi, 2013) who reported the ability of this plant extract in purifying drinking water. Thus, reducing the microbial load of the water sample.

The molecular screening for the presence of $R p o S$ gene in the selected isolates showed that majority of E. coli 0157:H7 carried this stress genes in them which may probably suggests their ability to withstand environmental stress. This is in concordance with the study by Parry-Hanson et al. (2010) who reported RpoS gene expression in acidadapted Escherichia coli 0157:H7 during lactoperoxidase and lactic acid challenge in tryptone soy broth. RpoS is the primary sigma factor for global regulation of genes associated with environmental stresses (Nickerson et al., 2004). Bacterial cells 
exposed to a large variety of harmful agents respond by increasing the cellular concentration of a stress sigma factor which replaces the house keeping sigma factor on the RNA polymerase enzyme, thereby changing its regulatory properties (Nickerson et al., 2004).

In conclusion, this study has revealed the effectiveness of some water treatment methods as these methods do not support the survival and growth of E. coli 0157:H7 and non-0157. However, some were found to be ineffective as these strains of $E$. coli could still survive after exposure to them. Moreover, the study revealed that stress sigma factor (RpoS gene) assists bacteria in surviving harsh conditions (treatment methods). In addition, bacteria causing waterborne diseases will survive if adequate concentration and exposure to agents used in water treatment methods are not observed. Consequently, in communities or households where this invaluable information, on survival pattern of bacteria causing waterborne disease, is lacking, high incidence of waterborne diseases will often be reported.

\section{References}

[1] Adesioye, F. A. \& Ogunjobi, A. A. (2013). Comparative study of persistence of Escherichia coli, Salmonellasp. and Shigella sp. in different water samples stored under various storage conditions. World Applied Sciences Journal, 26 (2): 181-188.

[2] Albashan, M. M. (2009). Acid tolerance of Escherichia coli 0157: H7 serotype and Salmonella typhi (A group D serotype) and their survival in apple and orange juices. World Journal of Medical Sciences, 4 (1): 33-40.

[3] Al-qadiri, A. M. Lu, X., Al-alami, N. I. and Rasco, B. A. (2011). Survival of Escherichia coli 0157:H7 and Campylobacter jejuni in bottled purified drinking water under different storage conditions. Journal of Food Protection, 74 (2): 254 - 260, https://doi.org/10.4315/0362-028x.jfp-10-368.

[4] Ansay, S. E., Darling, K. A. \& Kaspar, C. W. (1999). Survival of Escherichia coli 0157:H7 in ground-beef patties during storage at 2, $-2,15$ and then -2 degrees C, and -20 degrees. Journal of Food Protection, 62 (11): 1243-7, https://doi.org/10.4315/0362-028x62.11.1243.

[5] Berghloz, T. M. \& Whittam, T. S. (2007). Variation in acid resistance among enterohaemorrhagic E. coli in simulated gastric environment. Journal of Applied Microbiology, 102(2): 352-362, https://doi.org/10.1111/j.1365-2672.2006.03099.x.

[6] Berthe, M. R., Clermont, O., Denamur, E. \& Petita, F. (2013). Evidence for coexistence of distinct Escherichia coli populations in various aquatic environments and their survival in estuary water. Applied and Environmental Microbiology, 79 (15): 4684-4693, https://doi.org/10.1128/aem.00698-13.

[7] Bhagat, N., Vermani, M. \& Bajwa, H. S. (2016). Characterization of heavy metal (cadmium and nickle) tolerant Gram negative enteric bacteria from polluted Yamuna River, Delhi. African Journal of Microbiology Research, 10 (5): 127-137, https://doi.org/10.5897/ajmr2015.7769.
[8] Bichi, M. H. (2013). A review of the applications of Moringa oleifera seeds extract in water treatment. Civil and Environmental Research, 3 (8): 1-10.

[9] Bukar, A., Uba, A. \& Oyeyi, T. I. (2010). Antimicrobial profile of moringa oleifera lam. extracts against some food - borne microorganisms; Bayero Journal of Pure and Applied Sciences, 3 (1): 43- 48, https://doi.org/10.4314/bajopas.v3i1.58706.

[10] Clavero, M. R. S. \& Beuchat, L. R. (1996). Survival of Escherichia coli 0157:H7 in broth and processed salami as influenced by $\mathrm{pH}$, water activity, and temperature and suitability of media for its recovery. Applied and Environmental Microbiology, 62 (8): 2735-2740, https://doi.org/10.1128/aem.62.8.27352740.1996.

[11] Edberg, S. C., Rice, E. W., Karlin, R. J. \& Allen, M. J. (2000). Escherichia coli: the best biological drinking water indicator for public health protection. Journal of Applied Microbiology, 88: 106S-116S, https://doi.org/10.1111/j.1365-2672.2000.tb05338.x.

[12] Elsas, J. D., Semenov, A. V., Costa, R. \& Trevors, J. T. (2011). Survival of Escherichia coli in the environment; fundamental and public health aspect. ISME Journal, 5(2): 173-183, https://doi.org/10.1038/ismej.2010.80.

[13] Esemikose, E. E. \& Azeez, Z. (2013). Effects of solar disinfection on Escherichia coli and Klebsiella pneumoniae isolated from water samples. FUTA Journal of Research in Sciences, 2: 293-296.

[14] Fisch, F., Suarez, M., \& Mermoud, N. (2004). Flo antibacterial peptide from the tropical tree Moringa oleifera: A template for novel antibacterial agents. Travail de diploma, Universite De Lausanne, Lausanne, fevrier.

[15] Gordon, D.M., Oliver, E. \& Little-Field, W. J. (2006). The diversity of bacteriocins in Gram-negative bacteria. In: Riley, M. and Chavan, M. (eds). In Bacteriocins: Ecology and Evolution, Berlin Springer

[16] Ihssen, J. \& Egli, T. (2005). Global physiological analysis of carbon- and energy-limited growing Escherichia coli confirms a high degree of catabolic flexibility and preparedness for mixed substrate utilization. Environmental Microbiology, 7(10): 1568-1581, 2920.2005.00846.x.

[17] Islam, M., Doyle, M. P., Phatak, S. C., Millner, P. \& Jiang, X. (2004). Persistence of enterohemorrhagic Escherichia coli 0157:H7 in soil and on leaf lettuce and parsley grown in fields treated with contaminated manure composts or irrigation water. Journal of Food Protection, 67(7):1365-1370, https://doi.org/10.4315/0362-028x-67.7.1365.

[18] Jacob, A. \& Sumathy, J. A. (2011). Effect of citrus fruit peel extracts on pathogens causing gastrointestinal disorders. Advanced Biotechnology, 10 (3): 1-5

[19] Kim, J., Cho, M., Oh B, Choi, S. \& Yoon, J. (2004). Control of bacterial growth in water using synthesized inorganic disinfectant. Chemosphere, 55(5):775-780, https://doi.org/10.1016/j.chemosphere.2003.11.014.

[20] Kawahara, K., Tsuruda, K., Morishita, M. \& Uchida, M. (2000). Antibacterial effect of silver-zeolite on oral bacteria under anaerobic conditions. Dent Mater, 16(6):452-455, https://doi.org/10.1016/s01095641(00)00050-6.

[21] LeJeune, J. T., Besser, T. E. \& Rice, D. H. (2004). Longitudinal study of fecal shedding of Escherichia coli 0157:H7 in feedlot cattle: predominance and 
persistence of specific clonal types despite massive cattle population turnover. Applied Environmental Microbiology, 70(1): 377-384, https://doi.org/10.1128/aem.70.1.377-384.2004.

[22] Miller, W. L. (1998). Effects of UV radiation on aquatic humus: Photochemical principles and experimental considerations. In: Hessen, D. O. and Tranvik, L. J. (Eds.) Aquatic Humic Substances - Ecology and Biogeochemistry. pp. 125-143.

[23] Nannapaneni, R. Muthaiyan, A., Candall, P.G., Johnson, M.G. \& O'Bryan, C.A. (2008). Antimicrobial activity of commercial Citrus-based natural extracts against Escherichia coli 0157 isolates and mutant strains. Foodborne Pathogen and Diseases, 5 (5): 695-699, https://doi.org/10.1089/fpd.2008.0124.

[24] Nickerson, C. A., Ott, C. M., Wilson, J. W., Ramamurthy, R. \& Pierson, D. L. (2004). Microbial Responses to Microgravity and other Low-Shear Environments. Microbiology and Molecular Biology Review, 68(2): 345-361, https://doi.org/10.1128/mmbr.68.2.345361.2004.

[25] Ojiezeh, T. I., Nwachukwu, S. E. \& Udoh, S. J. (2011). Antimicrobial effect of Citrus aurantifolia juice and Veronica amygdalina on common bacteria isolates. Scholars Research Library, Der Pharma Chemica, 3 (1): 1-7.

[26] Oliveira, M., Vinas, I., Usall, J., Anguera, M. \& Abadias, M. (2012). Presence and survival of Escherichia coli 0157:H7 on lettuce leaves and in soil treated with contaminated compost and irrigation water. International Journal of Food Microbiology, 156(2):133-140, https://doi.org/10.1016/j.ijfoodmicro.2012.03.014.

[27] Oshoma, C. E., Aghimien, M. O. \& Bello, Z. O. (2009). Growth and survival of Escherichia coli in Kunun Zaki during storage. World Journal of Agricultural Sciences, 5 (4): 494-497.

[28] Parry-Hansona, A. A., .Joosteb, P. J. \& Buysa, E. M. (2010). Relative gene expression in acid-adapted Escherichia coli 0157:H7 during lactoperoxidase and lactic acid challenge in Tryptone Soy Broth. Microbiological Research, 165(7) (2010): 546 - 556, https://doi.org/10.1016/j.micres.2009.11.003.

[29] Russell AD \& Hugo WB (1994). Antimicrobial activity and action of silver. Prog Med Chem 31:351-370, https://doi.org/10.1016/s0079-6468(08)70024-9.

[30] Sakyi, P. A. and Asare, R. (2012). Impact of temperature on bacterial growth and survival in drinking water pipes, Research Journal of Environmental and Earth Science: 4 (8): 807-817.

[31] Saxena, K. L. \& Sewak, R. (2016). Livestock waste and its impact on human health. International Journal of Agricultural Sciences, 6 (7): 1084-1099.

[32] Semenov, A. V., van Overbeek, L. \& van Bruggen, A. H. (2009). Percolation and survival of Escherichia coli 0157:H7 and Salmonella enterica serovar Typhimurium in soil amended with contaminated dairy manure or slurry. Applied Environmental Microbiology, $\quad 75(10):$ 3206-3215, https://doi.org/10.1128/aem.01791-08.

[33] Silvestry-Rodriguez, N. Sicairos-Ruelas, E. E., Gerba, C. P. \& Bright, K. R. (2007). Silver as a Disinfectant. Rev Environ Contam Toxicol 191:23-45

[34] Suareze, M., Entenza, J. M., Doerries, C., Meyer, E., Bourquin, L., Sutherland, J., Marison, I., Moreillon, P. \& Mermod, N. (2003); Expression of a Plant-Derived Peptide Harboring Water-Cleaning and Antimicrobial Activities, Biotechnology and Bioengineering, 81 (1): 13-20, https://doi.org/10.1002/bit.10550.

[35] Suareze, M., Haenni, M., Canarelli, S., Fisch, F., Chodanowski, P., Servis, C., Michielin, O., Freitag, R., Moreillon, P. \& Mermod, N. (2005). Structure-function characterization and optimization of a plant-derived antibacterial peptide. Antimicrobial Agents and Chemotherapy, $49 \quad$ (9): $\quad 3847-3857$, https://doi.org/10.1128/aac.49.9.3847-3857.2005.

[36] Thilza, I. B., Sanni S., Isah, Z. A., Sanni, F. S., Talle, M. \& Joseph, M. B. (2010). In vitro Antimicrobial activity of water extract of Moringa oleifera leaf stalk on bacteria normally implicated in eye diseases; Academia arena, 2 (6): 80-82.

[37] Vital, M., Hammes, F. \& Egli, T. (2008). Escherichia coli 0157 can grow in natural freshwater at low carbon concentrations. Environmental Microbiology, 10(9): 2387-2396,

https://doi.org/10.1111/j.14622920.2008.01664.x.

[38] Wcisło, R. \& Chrost, R. J. (2000). Survival of Escherichia coli in Freshwater, Polish Journal of Environmental Studies, 9 (3): 215-222.

[39] World Health Organization (1996). Guidelines for Drinking-Water Quality, 2nd Ed. WHO, Geneva, Switzerland.

[40] World Health Organisation (2006). Guidelines for drinking water quality. First addendum to third edition, volume 1 recommendations. http://www.who.int/water-sanitationhealth/dwq/gdwq3rev/en/. 